\title{
Optimization of liver pate sterilization from the aspect of preserving nutritional value and ensuring food safety
}

\author{
Mladen Rasetal, Ivana Brankovic-Lazicl, Boris Mrdovic ${ }^{l}$, Branislav Baltic ${ }^{l}$, Becskei Zsolt ${ }^{2}$, \\ Vesna Djordjevic ${ }^{l}$
}

A b s tr a c t: Sterilization is a physical method of food preservation that, through high temperature over $100^{\circ} \mathrm{C}$ which destroys microorganisms and inactivates tissue enzymes. Safety and shelf-life of the canned liver pate (75 and 150 grams) is ensured with determined $F_{o}$ values $\geq 3$. Commercial sterility was achieved, but treatment intensity was too high $\left(F_{o}=12,07-15,93\right.$ and $\left.F_{o}=9,71-13,17\right)$ thus reduced the nutritional value of the food $\left(C_{o}=111-160\right.$ and $\left.C_{o}=123-180\right)$. Based on the measurements, under defined heat treatment conditions (20' heating time and $121.1^{\circ} \mathrm{C}$ autoclave medium under 2.5 bar pressure followed by 20-25' cooling time) it is suggested that effective sterilization should be reduced by 5 and 10 minutes, respectively. This way the safety of the product would not be compromised, negative impact of heat on the nutritional value would be reduced, whereby production efficiency would be increased and energy consumption would be reduced.

Keywords: Liver pate, Sterilization, $F_{o}$ value, $C_{o}$ value, food safety, thermal treatment

\section{Introduction}

Sterilization is the process of heat treatment of a can at a temperature higher than $100^{\circ} \mathrm{C}$, whereby a lethal value of at least $\mathrm{Fo}=3$ must be achieved in the thermal center of the product (Anonymous, 2019). The shelf-life of the can depends primarily on the degree of bacterial destruction (biological sterility), which is difficult to achieve due to the overly harsh heat treatment regime on the product's sensory properties. The sterilization mode is therefore adjusted to achieve commercial sterility (FSIS, 2005). Commercial sterility is achieved by applying heat of sufficient intensity to independently or in combination with other elements of importance (degree of initial contamination of the stuffing, stuffing weight, stuffing temperature, packaging) to make the product safe by eliminating the existing microbiological risk, while preventing the microbial growth by preventing them from following the label regarding the intended storage conditions (sterilized can is stored at temperatures up to $+25^{\circ} \mathrm{C}$ (FAO).

The characteristic of commercially sterilized food is adequate heat treatment which eliminates all pathogenic microorganisms and reduce presence of defect-causing micro-organisms, to a level where they do not pose a threat to consumer health or affect the quality and degree of acceptability of the final product. Can is a commercially sterilized food contained in hermetically sealed container. "Hermetically sealed container" means a container designed to prevent the entry of hazardous substances (Anonymous, 2004).

Prior to filling at the production line, the prepared cans must be clean, free from irregularities and damage which can impair the integrity of the can. Also during the closing phase, attention should be paid to the proper execution of the procedure itself visual and manual damage control (Codex alimentarius, 2011). The filled cans shall be sealed in such a way as to ensure good sealing and prevent recontamination of the contents after heat treatment, as well as during storage, distribution and sale. The higher the temperature of sterilization the greater is the rate of thermal destruction. The rate of thermal destruction is also affected by the nature of the product (liquids heat faster than solids) and the container size (FAO).

Liver and fat as a basic raw material for liver pate must have optimal hygienic and technological quality that can be ensured by measures such as the selection of an animal, adequate preparation for slaughter and the performance of slaughter operations, and product processing, until it is closed 
into the can. Used components are regularly stuffed in metal containers. For this purpose, cans of white tin and aluminum are used and containers of refined aluminum thin strip. The can is made up of a body, a bottom and a cover of different shape and size.

For the purpose of reliable control of the efficiency of the heat treatment process, a unit of lethality of the heat treatment process has been introduced, which designates it as $\mathrm{F}$ value. When heated in a humid environment, microorganisms die out in logarithmic cycles, where the total lethality or lethal capacity of the heat treatment process is expressed by $\mathrm{F}$ value. It has been defined that the sterilization process should be such as to provide 12 decimal reductions in the number of Clostridium botulinum spores at sterilization temperature $-121.1^{\circ} \mathrm{C}$ (Vukovic, 2012). Because greatest danger for meat cans stored at room temperature represent spores of mesophilic types A and B Clostridium botulinum, the F value for the sterilization procedure, according to the Regulations, is calculated according to this microorganism (Anon, 2019; FAO, Codex alimentarius 2011; FSIS, 2005).

As a consequence of heat treatment, meat products lose more or less nutritional value, which depends on the temperature and the length of its action. The higher the temperature and the time of action, the greater the loss of nutritional value (Amit et al., 2017). In addition to ensuring the safety and shelf-life of food, the equally important task of heat treatment is to preserve the biological value of meat and meat products (Vukovic, 2012). During heat treatment of the liver, irreversible changes in the protein ferritin occurs at temperatures above $80^{\circ} \mathrm{C}$ (Prochaska et al. 2000).

$\mathrm{C}_{\mathrm{o}}$ value (Cooking value) expresses the reduction in the nutritional value of heat treated products.
For $\mathrm{C}_{\mathrm{o}}$ value there are no standards and recommendations as well as for the F-value, and as the optimal heat treatment process is one that for a given value of $\mathrm{F}_{\mathrm{o}}$, has a smaller value of $\mathrm{C}_{\mathrm{o}}$ (Vukovic, 2012).

Heat treatment provides food with desirable sensory properties and it becomes more digestible, but too intense heat treatment leads to a loss of nutritional value. For this reason, aim of this paper is to determine optimum between the conservation effect of heat treatment and the preservation of the nutritional value of canned liver pate.

\section{Materials and methods}

During period February-April 2018, in domestic meat industry, during regular production, systematic monitoring of sterilization process of liver pate (a product belonging to the group of "cooked sausages", which is sterilized in can, in accordance with legal provisions - Anon, 2019) was implemented. Sterilization monitoring was performed on same autoclave (horizontal overpressure autoclave that can accommodate four carts) on two types of same product with different weights and packaging methods:

1. Liver pate $75 \mathrm{~g}$ in two-piece soft aluminum sheet

2. Liver pate $150 \mathrm{~g}$ in a two-part hard-drawn tray

For each product, an existing heat treatment plan is verified and ways of optimizing the production process are discussed.

Measurements were made by a thermocouple type 'Ellab' model E Val-Pro. Thermocouples with compensating cables were used, 4 probes which were

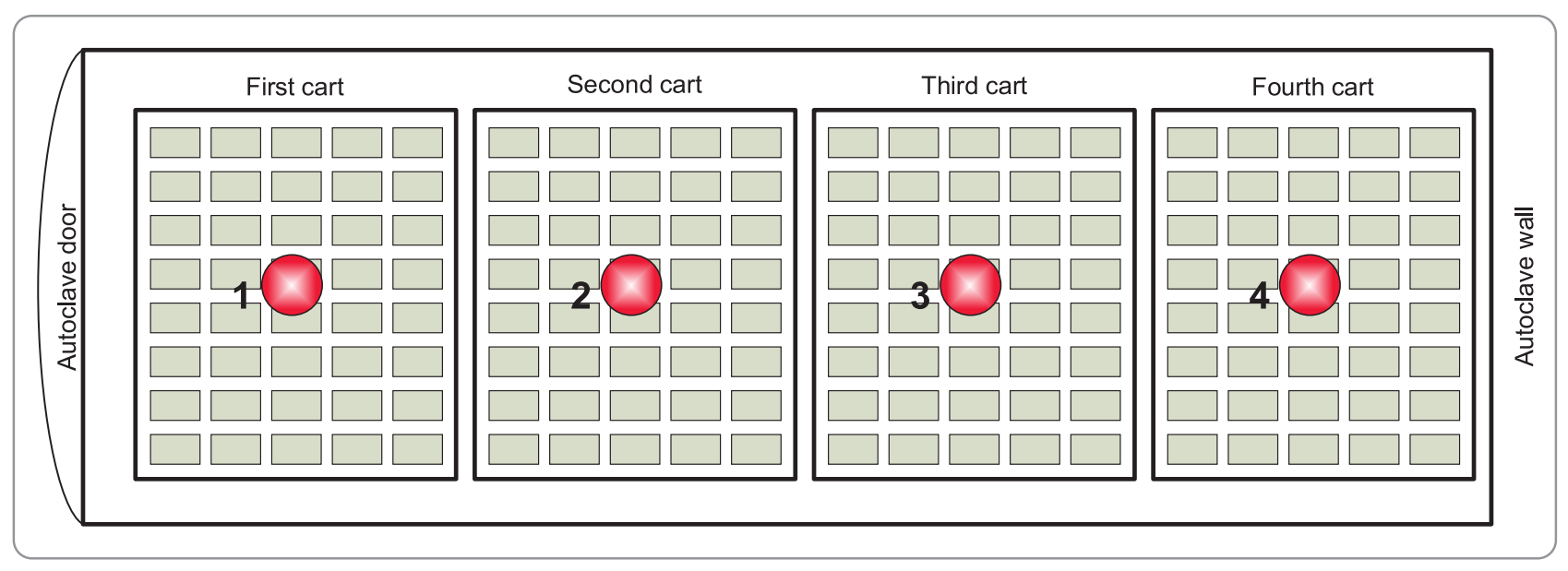

Scheme 1. Positions of the placed probes in the autoclave viewed from the side:

Legend: - Probe placed in the geothermal center of the product 


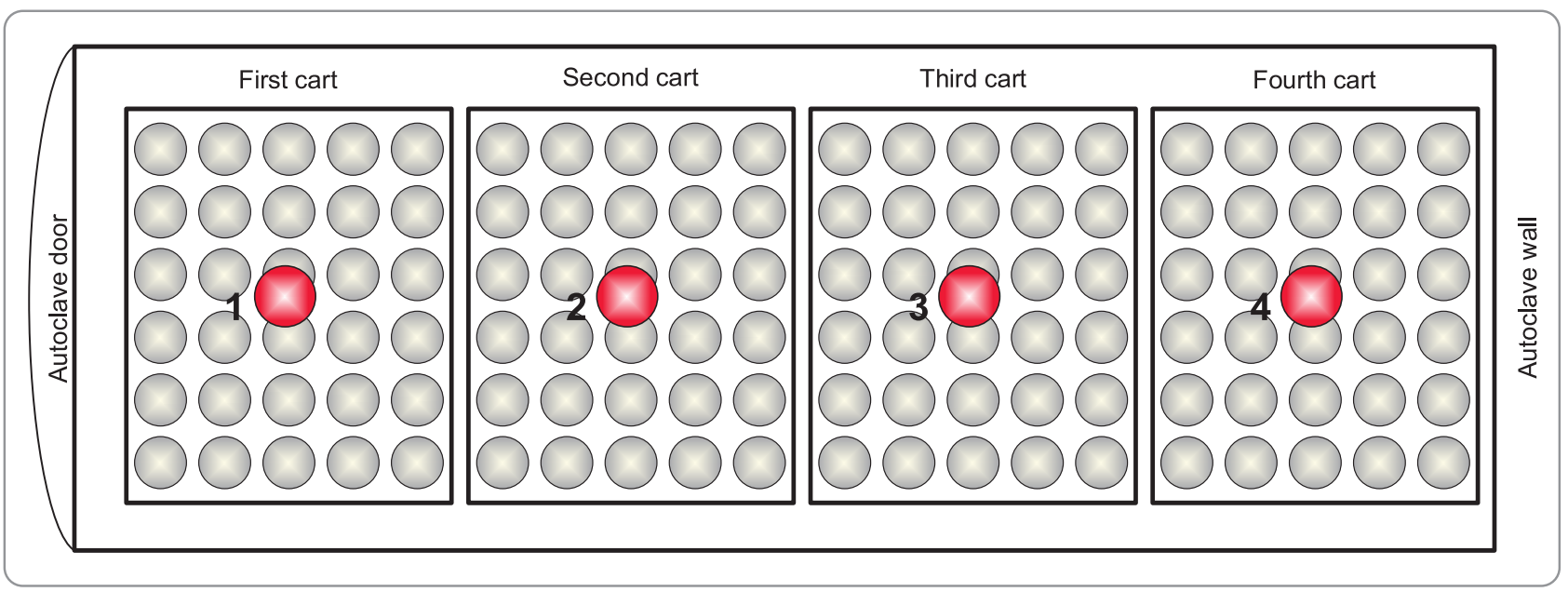

Scheme 2. Positions of the placed probes in the autoclave viewed viewed from above:

Legend: - Probe placed in the geothermal center of the product

placed in the geothermal center of canned liver pate. Position on used probes were represented graphically (Schemes 1 and 2) and was identical at each check.

The obtained data were processed at the Meat Hygiene and Technology Institute, Belgrade, using commercial computer programs.

$F_{o}$ values were automatically read in real time on a thermocouple E Val-Pro (manufacturer Ellab Danmark, 2018. year), compared to temperature readings in the geothermal center of the product and recorded every 2-3 minutes.

$\mathrm{C}_{\mathrm{o}}$ values were determined graphically by means of the semi-logarithmic TDT diagram (Chart 1), in which the previously constructed of two straight lines: $\mathrm{C}_{\mathrm{o}}=1\left(1\right.$ minute at $100^{\circ} \mathrm{C}$, with $\left.\mathrm{a}=33^{\circ} \mathrm{C}\right)$ and $\mathrm{F}_{\mathrm{o}}=$ $1\left(1\right.$ minute at $121,1^{\circ} \mathrm{C}$, with $\left.\mathrm{a}=10^{\circ} \mathrm{C}\right)$. In order to

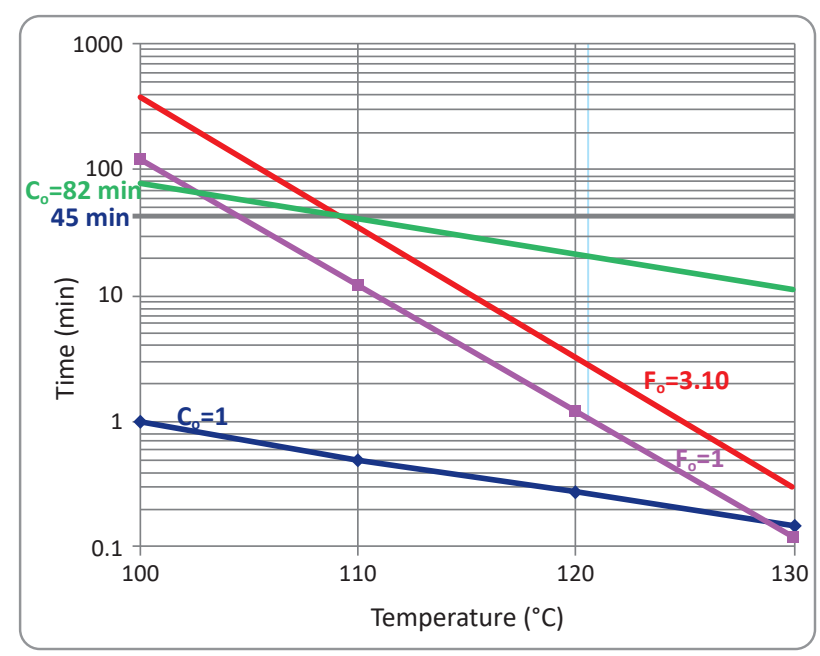

Chart 1. Semi-logarithmic Thermal Death Time (TDT) diagram (Rašeta et al., 2018) determine the $\mathrm{C}_{\mathrm{o}}$ value, the $\mathrm{F}_{\mathrm{o}}$ value of the sterilization process should be known and how long in minutes lasted the temperature equal to or higher than $100^{\circ} \mathrm{C}$ in the thermal center of the product. $\mathrm{C}_{\mathrm{o}}$ value was obtained by connecting a point which is parallel with a line $\mathrm{C}_{\mathrm{o}}=1$, and which passes through a point of intersection lines which are plotted based on the data of $F_{0}$ value (which is parallel with the line of $F_{o}=1$ ) and the straight line is drawn on the basis of the time of operation temperature greater than $100^{\circ} \mathrm{C}$ for a given mode of heat treatment (Vukovic, 2012; Raseta et al., 2018).

\section{Results}

Sterilization of canned liver pate $75 \mathrm{~g}$ in two-piece soft aluminum sheet

The results of sterilization validation are presented on the charts 1-2. Validation were performed during the regular production of sterilized liver pate. The established results (temperature in the geothermal center and $F_{0}$ value) are presented in charts $(2-3)$. A concise measurement comment is provided for each measurement.

Temperature change in geothermal center of canned liver pate 75 grams package in two-piece soft aluminum sheet, during sterilization is presented on chart 1 . Determined $F_{o}$ values in the geothermal center of canned liver pate $75 \mathrm{~g}$ package is presented on chart 2.

- Chart 2. Temperature change in geothermal center of canned liver pate $75 \mathrm{~g}$

- Chart 3. Determined $F_{o}$ values in the geothermal center of canned liver pate $75 \mathrm{~g}$ 
Sterilization of canned liver pate 75 grams packaged in two-piece soft aluminum sheet, with a glued lid, lasted 1 hour and 19 minutes. The heat treatment formula is:

$$
T_{o}=20^{\prime}+\frac{35^{\prime}}{121.1^{\circ} \mathrm{C} / 2.5 \text { bar }}+24^{\prime}
$$

Sterilization temperature of $121.1^{\circ} \mathrm{C}$ and a pressure of 2.5 bars has been reached for 20 minutes in the autoclave medium. The effective sterilization time was 35 minutes and cooling time was 24 minutes. In the geothermal center of the product, in all four inspection sites, where probes were placed, $\mathrm{F}_{\mathrm{o}}$ values were over 3 , which is the sterilization minimum, and ranged from 12.07 to 15.93 .

The obtained $\mathrm{F}_{\mathrm{o}}$ values during sterilization of liver Pate $75 \mathrm{~g}$, in two-piece soft aluminum sheet, ensured safety of the final product.

\section{Sterilization of canned liver pate $150 \mathrm{~g}$ in a two-part hard-drawn tray}

The results of sterilization validation are presented on the charts 3-4. Validation were performed during the regular production of sterilized liver pate. The established results (temperature in the geothermal center and $F_{o}$ value) are presented in charts (4-5). A concise measurement comment is provided for each measurement.
Temperature change in geothermal center of canned liver pate 150 grams package in two-part hard-drawn tray, during sterilization is presented on chart 3. Determined $F_{o}$ values in the geothermal center of canned liver pate $150 \mathrm{~g}$ package is presented on chart 4.

- Chart 4. Temperature change in geothermal center of canned liver pate $150 \mathrm{~g}$

- Chart 5. Determined $\mathrm{F}_{\mathrm{o}}$ values in the geothermal center of canned liver pate $150 \mathrm{~g}$

Sterilization of canned Liver pâté 150 grams packaged in two-part hard-drawn tray, lasted 1 hour and 36 minutes. The heat treatment formula is:

$$
T o=18^{\prime}+\frac{50^{\prime}}{121.1^{\circ} \mathrm{C} / 2.5 \mathrm{bar}}+28^{\prime}
$$

Sterilization temperature of $121.1^{\circ} \mathrm{C}$ and a pressure of 2.5 bars has been reached for 18 minutes in the autoclave medium. The effective sterilization time was 50 minutes and cooling time was 28 minutes. In the geothermal center of the product, in all four inspection sites, where probes were placed, $\mathrm{F}_{\mathrm{o}}$ values were over 3 , which is the sterilization minimum, and ranged from 9.71 to 13.17 .

The obtained $\mathrm{F}_{\mathrm{o}}$ values during sterilization of liver Pate $150 \mathrm{~g}$, in two-part hard-drawn tray, ensured safety of the final product.

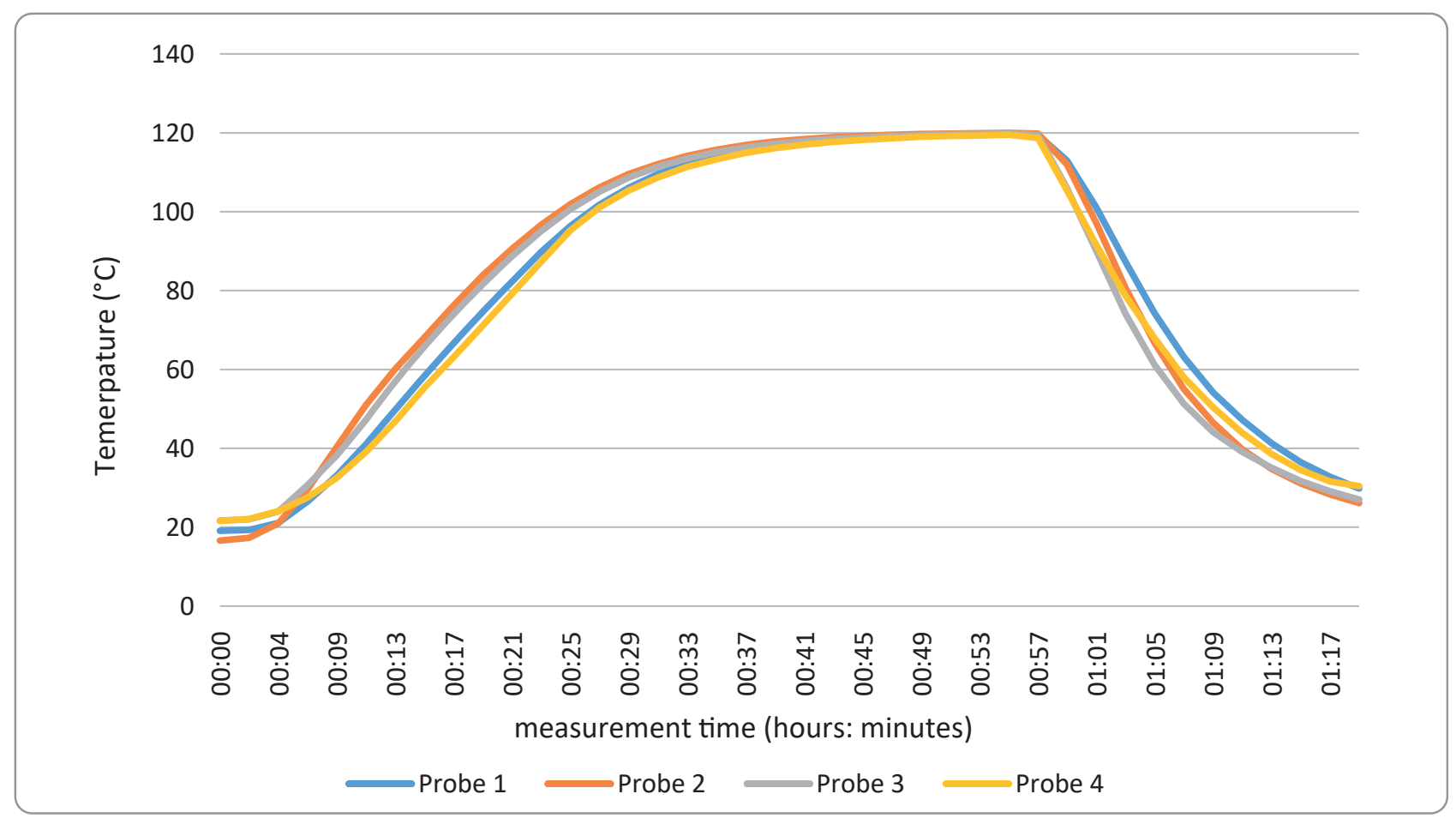

Chart 2. Temperature change in geothermal center of canned liver pate $75 \mathrm{~g}$ 


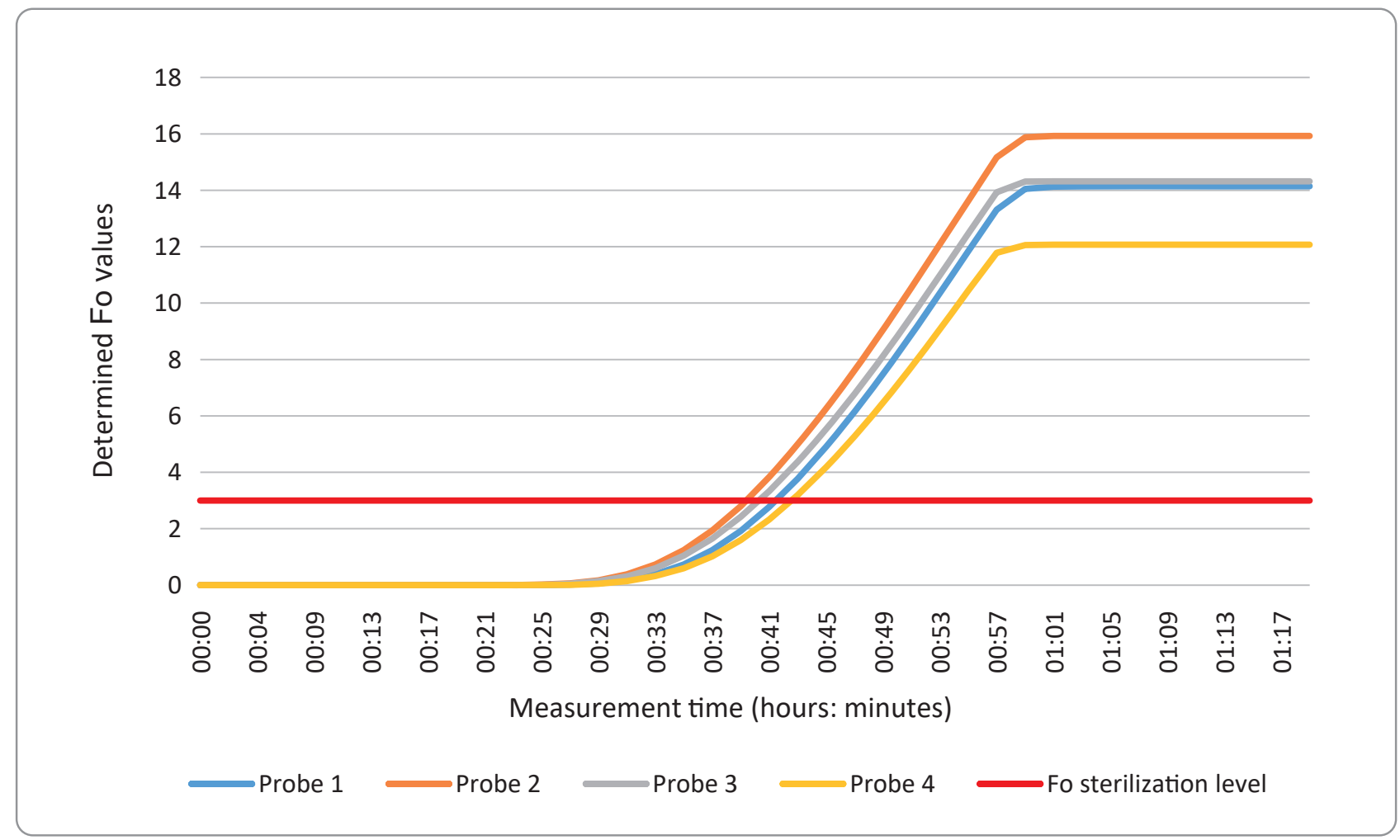

Chart 3. Determined Fo values in the geothermal center of canned liver pate $75 \mathrm{~g}$

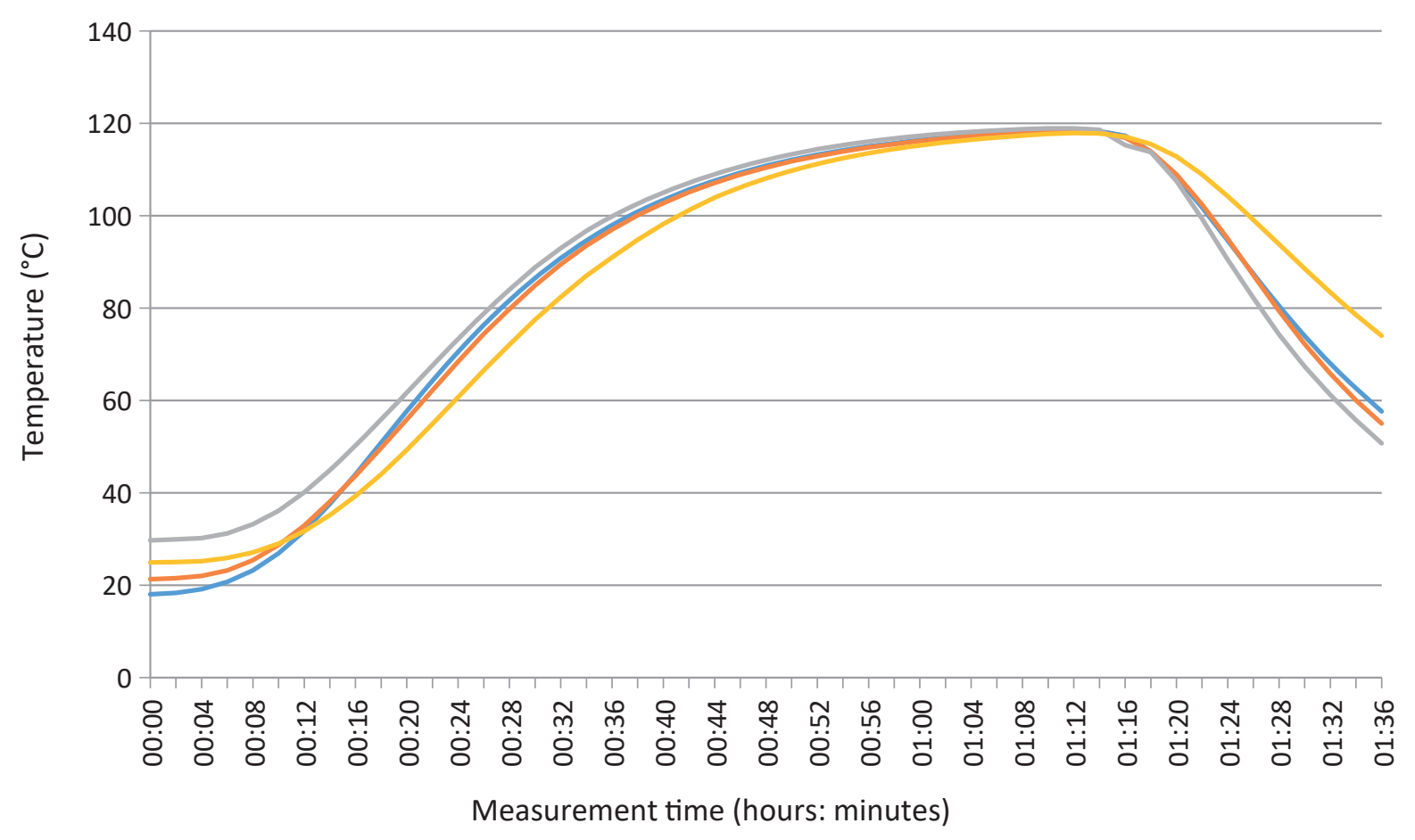

Probe $1 \longrightarrow$ Probe $2 \longrightarrow$ Probe $3 \longrightarrow$ Probe 4

Chart 4. Temperature change in geothermal center of canned liver pate $150 \mathrm{~g}$ 


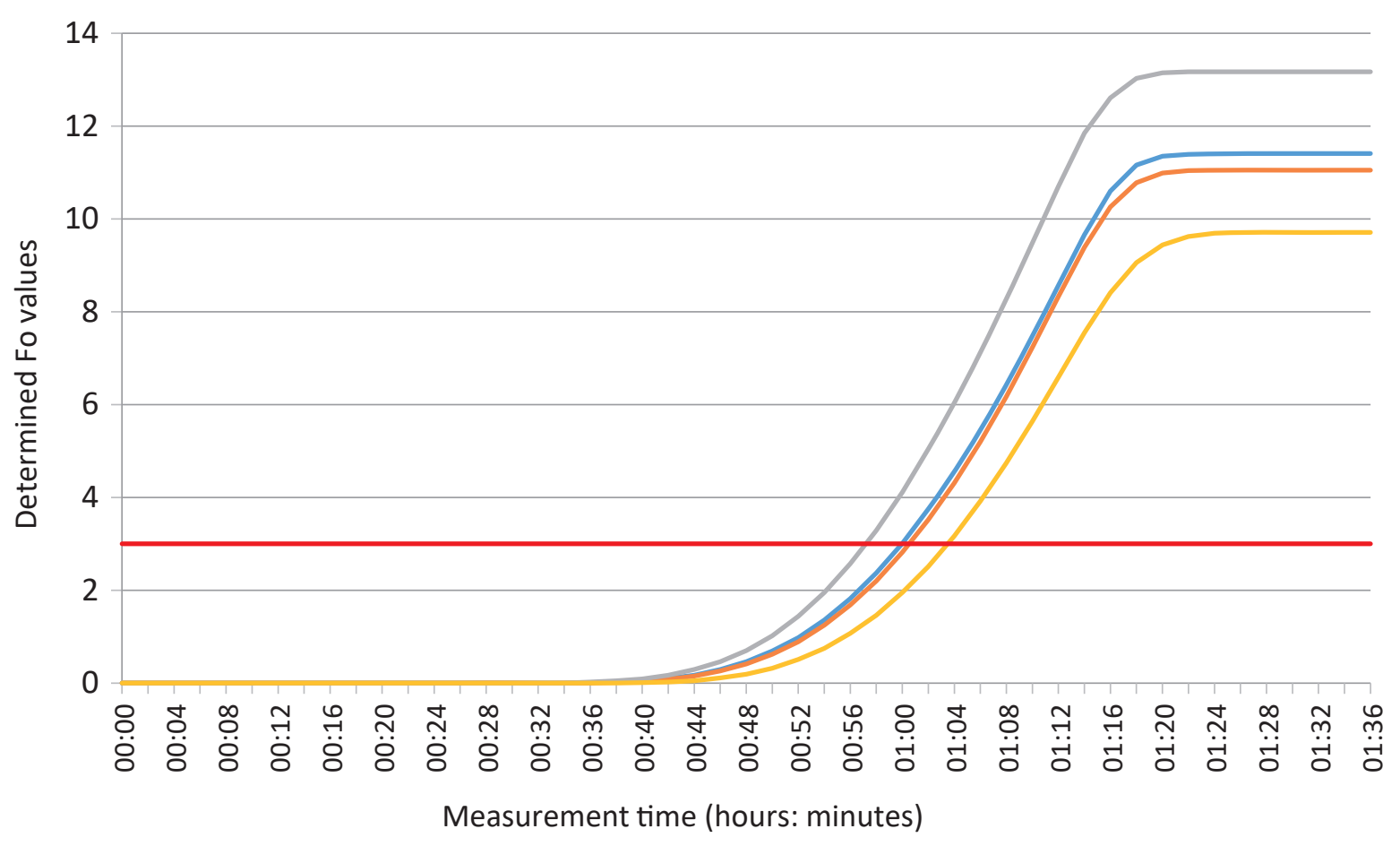

CProbe $1 \longrightarrow$ Probe $2 \longrightarrow$ Probe $3 \longrightarrow$ Probe $4 \quad$ Fo sterilization level

Chart 5. Determined Fo values in the geothermal center of canned liver pate $150 \mathrm{~g}$

Summary table of heat treatment programs with determined $F_{o}$ and $C_{o}$ values

In order to adequately assess the sterilization process, in Table 1 heat tretments regimes of canned liver pate, with minimum and maximum determined $\mathrm{F}_{\mathrm{o}}$ values and calculated $\mathrm{C}_{\mathrm{o}}$ values are listed. in this way the process of commercial sterilization of liver pate was outlined. Commercial sterility $F_{o}$ value of $\geq 4$ for sterilized meat products in cans essential from the aspect of quality. Therefore, there is always a current tendency that produces thermal processing as low as possible.
Summary table of current heat treatment programs with optimization proposal

Although the variation in sterilization process dynamics exist, there is the possibility of shortening the effective sterilization time. Only after the autoclave work standardization and elimination of the current present variations it is indicated by access validation of the proposed optimized regime. Then it will be possible to perceive the maximum effect of the preservation of the biological value of the cans.

Table 1. Display of sterilization regimes, and determined Fo and Co values during heat treatment of canned liver pate 75 and 150 grams

\begin{tabular}{|l|c|c|c|c|c|}
\hline \multirow{2}{*}{ Product and package } & Heat treatment plan & \multicolumn{2}{|c|}{ Fo values } & \multicolumn{2}{c|}{ Co values (min) } \\
\cline { 3 - 6 } & & Min & Max & Min & Max \\
\hline $\begin{array}{l}\text { Liver pate } 75 \mathrm{~g} \text { in two-piece } \\
\text { soft aluminum sheet }\end{array}$ & $T_{0}=20^{\prime}+\frac{35^{\prime}}{121.1^{\circ} \mathrm{C} / 2.5 \mathrm{bar}}+24^{\prime}$ & 12,07 & 15,93 & 111 & 160 \\
\hline $\begin{array}{l}\text { Liver pate } 150 \mathrm{~g} \text { in a two-part } \\
\text { hard-drawn tray }\end{array}$ & $T_{o}=18^{\prime}+\frac{50^{\prime}}{121.1^{\circ} \mathrm{C} / 2.5 \mathrm{bar}}+28^{\prime}$ & 9,71 & 13,17 & 123 & 180 \\
\hline
\end{tabular}


Table 2. Proposed heat treatment plan corrections for tested products

\begin{tabular}{|l|l|l|}
\hline Product and package & Current heat treatment mode & Proposed heat treatment regime \\
\hline $\begin{array}{l}\text { Liver pate } 75 \mathrm{~g} \text { in two-piece soft } \\
\text { aluminum sheet }\end{array}$ & $T o=20^{\prime}+\frac{35^{\prime}}{121.1^{\circ} \mathrm{C} / 2.5 \mathrm{bar}}+24^{\prime}$ & $T o=20^{\prime}+\frac{30^{\prime}}{121.1^{\circ} \mathrm{C} / 2.5 \mathrm{bar}}+20^{\prime}$ \\
\hline $\begin{array}{l}\text { Liver pate } 150 \mathrm{~g} \text { in a two-part } \\
\text { hard-drawn tray }\end{array}$ & $T o=18^{\prime}+\frac{50^{\prime}}{121.1^{\circ} \mathrm{C} / 2.5 \mathrm{bar}}+28^{\prime}$ & $T o=20^{\prime}+\frac{40^{\prime}}{121.1^{\circ} \mathrm{C} / 2.5 \mathrm{bar}}+25^{\prime}$ \\
\hline
\end{tabular}

\section{Discussion}

In the system of integrated control of production and processing of meat according to the rules of HACCP concept (Hazard Analysis Critical Control Points) a special place belongs to the control of heat treatment. In all HACCP plans, heat treatment is designated as a Critical Control Point (CCP) and is a place where the existing hazard is eliminated or minimized (Surak and Wilson, 2014). Safety level for canned food, for continental climate conditions, are defined in domestic legislative (Anonymous, 2019) as statutory minimum of $F_{o} \geq 3$, and then it is considered that spores of thermoresistant type $\mathrm{A}$ and B Clostridium botulinum which may be present, are with certainty destroyed (Vukovic, 2012). According to FAO recommendations $(F A O, 2019)$ based on microbiological risk assessment, sterilization of canned meat products should achieve $\mathrm{F}_{\mathrm{o}}$ values of $4-5,5$, while the temperature should be in range $117-130^{\circ} \mathrm{C}$, depending on characteristics of the products.

The sterilization temperature used is exactly proportional to the antimicrobial effect (Vukovic, 2012). For example, spores of mesophilic types Clostridium botulinum are destroyed at $100^{\circ} \mathrm{C}$ after 330 minutes and at $120^{\circ} \mathrm{C}$ in four minutes (FAO, 2019).

Optimal thermal regimes should satisfy the conditions of lethality necessary to destroy harmful microorganisms and to minimize the biological value of the product (Codex alimentarius, 2011). High temperature necessary for the destruction / inactivation of thermoresistant spores, repercusses negatively on sensory properties and promotes the occurrence of abiotic changes in the can during storage. Thermal processing results in thermal denaturation of the protein, resulting in a decrease in volume, release of water, the formation of coarse and tough consistency, as well as a loss of the meat's ability to bind water.
In domestic meat industry, it is often the case that microbiologically flawless, practically sterile meat cans filling have a softer consistency, more or less pronounced brown color and a burnt aroma. This is practiced by manufacturers who, in excessive heat treatment rather than in hygiene mode and good manufacturing practice, find a solution for the good sustainability of their products. Products treated in this way have less biological value, and due to higher energy consumption, the profitability of production is always lower.

During sterilization process monitoring in autoclave, uneven dynamics is noticeable on different autoclave medium spots and considerable variation $F_{0}$ value was achieved during measurement (12,07-15,93 for liver pate $75 \mathrm{~g}$ packed in two-piece soft aluminium sheet and 9,71-13,17 for $150 \mathrm{~g}$ package of the same product in two-part hard-drawn tray). To fully comprehend the qualitative changes in cans differently positioned in the medium of the autoclave and to evaluate nutritive value of the product, $\mathrm{C}_{\mathrm{O}}$ values were determined using TDT diagram (Chart 1). Obtained results showed variations presented in Table (111-160 minutes for liver pate 75 grams and 123-180 minutes for liver pate 150 grams). Longer effective sterilization time of liver pate of 150 grams (50 minutes), compared with sterilization of liver pate of 75 grams (35 minutes), resulted in higher $\mathrm{C}_{\mathrm{o}}$ values, although $\mathrm{F}_{\mathrm{o}}$ values are lower.

The established $\mathrm{F}_{\mathrm{o}}$ values in sterilization of liver pate of $150 \mathrm{~g}(9,71-13,17)$ are higher than in other studies $(7,24-8,58)$ that had a longer effective sterilization time (55 minutes), lower temperature of autoclave medium $\left(114^{\circ} \mathrm{C}\right)$, and higher pressure (3.2 bar) (Raseta et al., 2016). A high-quality and well-maintained autoclave and HACCP based everyday work practice, can provide us with the opportunity for further optimization and reduction of $F_{0}$ value in sterilization of liver pate to average values of $3.81 \pm 0,5$ gained on effective sterilization time of 45 minutes. Reducing the effective sterilization time 
by ten minutes, resulted in a $19.6 \%$ increase in the cooking value of the product. The average $\mathrm{C}_{\mathrm{o}}$ value for regular sterilization regime was $109,83 \pm 1,33$, while for the optimized regime, it was $88,67 \pm 4,27$ minutes (Raseta et al., 2018). It is necessary to stabilize dynamics of the autoclave work, in order to reduce the existing sterilization dynamics variation.

The table 2 shows a proposal of a sterilization process optimization, which involves settling of autoclave, identical at each sterilization conditions (temperature of $121.1^{\circ} \mathrm{C}$ and pressure of 2.5 bar), whereby the heat-up time should be the same, or with minimal fluctuation, in each round.

Food safety can be improved with preventive approach, and appropriate management during processing of liver pate (raw material selection, adequate temperature regime and storage conditions, within the framework of the food security system that has been a legal obligation in our country since 2009. year (Anonymous, 2009). Determining the degree of initial contamination of the liver pate stuffing before heat treatment, can provide us with information on the hygiene of the raw material and the production process itself (Raseta et al., 2016). Since the main responsibility for food safety has food business operator, it's obligation is to define and implement appropriate measures of good hygiene practices (GHP) and Good Manufacturing Practice (GMP) and methods based on the principles of Hazard Analysis and Critical Control Points (HACCP), in order to achieve the objectives of food safety (Food Safety Objectives) defined in food regulations (Anonymous 2002, 2004, 2004a, 2004b, 2004c). Based on the risk analysis, the existing risk should be recognized and eliminated or reduced to an acceptable level.

Optimal thermal regimes should satisfy the conditions of lethality necessary for the destruction of harmful micro-organisms and to minimize the biological value of the product (Codex alimentarius, 2011). High-temperature cooking methods generate compounds that may contribute to carcinogenic risk, but their role is not yet fully understood ( WHO,
2015). Due to high amounts of fat and non-haeme iron as well as the manufacturing process itself, liver pate is highly susceptibile to lipid oxidation (Lorenzo \& Pateiro M, 2013). However, fat is an important source of fatty acids and is important to balance the ratio between saturated and unsaturated fatty acids, rather than exclude it from the diet.

Success of the sterilization process is determined by reaching minimum $F_{0}=3$ in geothermal center of the canned meat product, upon completion of the heat treatment process. Then it is considered that the spores of thermosetting type $\mathrm{A}$ and B Clostridum botulinum which may be present, are with certainty destroyed (Anon, 2019; FAO, Codex alimentarius 2011).

\section{Conclusion}

Monitoring of the process of sterilization of liver pate showed that the determined $\mathrm{F}_{\mathrm{o}}$ values were 12.07-15.93 (liver pate $75 \mathrm{~g}$ ) and 9.71-13.17 (liver pate $150 \mathrm{~g}$ ) which ensured the food safety of product and $\mathrm{C}_{\mathrm{o}}$ values were $111-160$ (liver pate $75 \mathrm{~g}$ ) and 123-180 (liver pate $150 \mathrm{~g}$ ).

Considering the determined $\mathrm{F}_{\mathrm{o}}$ and $\mathrm{C}_{\mathrm{o}}$ values, sterilization of canned liver pate $75 \mathrm{~g}$ and $150 \mathrm{~g}$ is needlessly high and sterilization process should be optimized by reducing effective sterilization time and reducing the $\mathrm{C}_{\mathrm{o}}$ value..

Reducing the effective sterilization time by 5 (liver pate $75 \mathrm{~g}$ ) and 10 minutes (liver pate $150 \mathrm{~g}$ ) per production batch did not endanger the safety of the product, while reducing unnecessary energy consumption, could open up the space for increased production and improved the nutritional properties of the product.

Optimized heat treatment regime with reduced effective sterilization time can be applied in regular production, but it is necessary to ensure that sterilization dynamics in all parts of medium of the autoclave should be carried out as uniformly as possible. It requires regular maintenance and control of the equipment. 


\title{
Optimizacija postupka sterilizacije jetrene paštete sa aspekta osiguranja bezbednosti i očuvanja biološke vrednosti
}

\author{
Mladen Rašeta, Ivana Branković-Lazić, Boris Mrdović, Branislav Baltić, Becskei Zsolt, Vesna Đorđević
}

A p s tr a kt: Sterilizacija je fizički metod konzervisanja hrane, koji delovanjem temperature preko $100^{\circ} \mathrm{C}$ uništava mikroorganizme i inaktivira tkivne enzime. Bezbednost i održivost jetrene paštete u konzervi (pakovanja $75 \mathrm{~g}$ i $150 \mathrm{~g}$ ) je osigurana utvrđivanjem Fo vrednosti, koja mora da bude iznad 3. Pri proveri režima sterilizacije utvrđen je tretman intenzivniji od potrebnog (Fo=12,07-15,93 and $\left.F_{0}=9,71-13,17\right)$ koji je osiguravao bezbednost proizvoda, ali je imao za posledicu smanjenje biološke vrednosti $($ Co $=111-160$ and $\mathrm{Co}=123-180$ ). Na osnovu sprovedenih merenja i u skladu sa definisanim uslovima sterilizacije (20'zagrevanja do dostizanja efektivne temperature sterilizacije od $121,1^{\circ} \mathrm{C}$ i pritiska autoklava 2,5 bar-a, efektivno vreme sterilizacije 35-50'i vreme hlađenja 20-25') predlaže se smanjenje efektivnog vremena sterilizacije za 5-10 minuta. Time bezbednost proizvoda nije ugrožena, dok se smanjuje negativni uticaj na biološku vrednost, pri čemu se povećava efikasnost proizvodnje uz smanjenje utroška energije

Ključne reči: Jetrena pašteta, Sterilizacija, Fo vrednost, Co vrednost, Bezbednost hrane, Toplotni tretman.

Disclosure statement: No potential conflict of interest was reported by the authors.

Acknowledgements: This study was funded by grants TR 31083 and III 46009 from the Ministry of Education, Science and Technological Development, Republic of Serbia

\section{References}

Amit, S. K., Uddin, M., Rahman, R., Rezwanul, I. \& Mohidus, S. (2017). A review on mechanisms and commercial aspects of food preservation and processing. Agriculture \& Food Security, 6(51),1-22.

Anonymous (2019). Rulebook on the quality of minced meat, semi-finished meat products and meat products. Official Gazette of the Republic of Serbia, 50.

Anonymous (2009). Food safety law. Official Gazette of the Republic of Serbia, 41.

Anonymous (2004). Regulation (EC) No 852/2004 on the hygiene of foodstuffs.

Anonymous (2004a). Regulation (EC) No 853/2004 on specific hygiene rules for on the hygiene of foodstuffs.

Anonymous (2004b). Regulation (EC) No 854/2004 on specific rules for the organisation of official controls on products of animal origin intended for human consumption.

Anonymous (2004c). Regulation (EC) No 882/2004 on official controls performed to ensure the verification of compliance with feed and food law, animal health and animal welfare rules.

Codex alimentarius (2011). Code of hygienic practice for low and acidified low acid canned foods. (CAC/RCP 23-1979) http://www.fao.org/fao-who-codexalimentarius/codex-texts/codes-of- practice/en/

FAO (2019). Canning/Sterilization of meat products - Principles of food canning http://www.fao.org/3/R6918E/ $\underline{\text { R6918E02.htm (accessed 01.12.2019.) }}$
FSIS (2005). Directive, 7530.2 10/20/05, Verification acitvities in canning operations that choose to follow the canning regulations http://www.fsis.usda.gov/OPPDE/rdad/FSISDirectives $/ 75302 . p d f$

Lorenzo, J. M. \& Pateiro M (2013). Influence of fat content on physico-chemical and oxidative stability of foal liver pate. Meat Sceince, 95, 330-335.

Prochaska, J. L., Nguyen, T. X., Donat, N., Piekutowski, V. W. (2000). Effects of food processing on the thermodynamic and nutritive value of foods: literature and database survey. Medical Hypotheses, 54(2), 254-262.

Raseta M., Nikolic, A., Petrovic, N., Djordjevic, V., Mrdovic, B., Jankovic, V. \& Nastasijevic, I. (2016). Liver pate: process hygiene, quality parameters and thermal process. Meat Technology, 57(1), 11-21.

Raseta, M., Mrdovic, B., Djordjevic, V., Polacek, V., Besckei, Z., Brankovic-Lazic, I. \& Vasilev, D. (2018). Determination of Co-value as an indicator of nutritive value of pate sterilized by regular and optimized regimes. Veterinarski glasnik, 72(2), 101-111.

Surak, J. \& Wilson, S. (2014). The Certified HACCP auditor Handbook, Third edition. Milwaukee, Wisconsin : Quality Press. 2014. eBook., Database: eBook Academic Collection (EBSCOhost).

Vukovic, I. (2012). Osnove tehnologije mesa, IV izdanje, Veterinarska komora Srbije, Beograd.

WHO (2015). Q\&A on the carcinogenicity of the consumption of red meat and processed meat https://www.who.int/features/qa/cancer-red-meat/en/ (Accessed 01.12.2019.) 